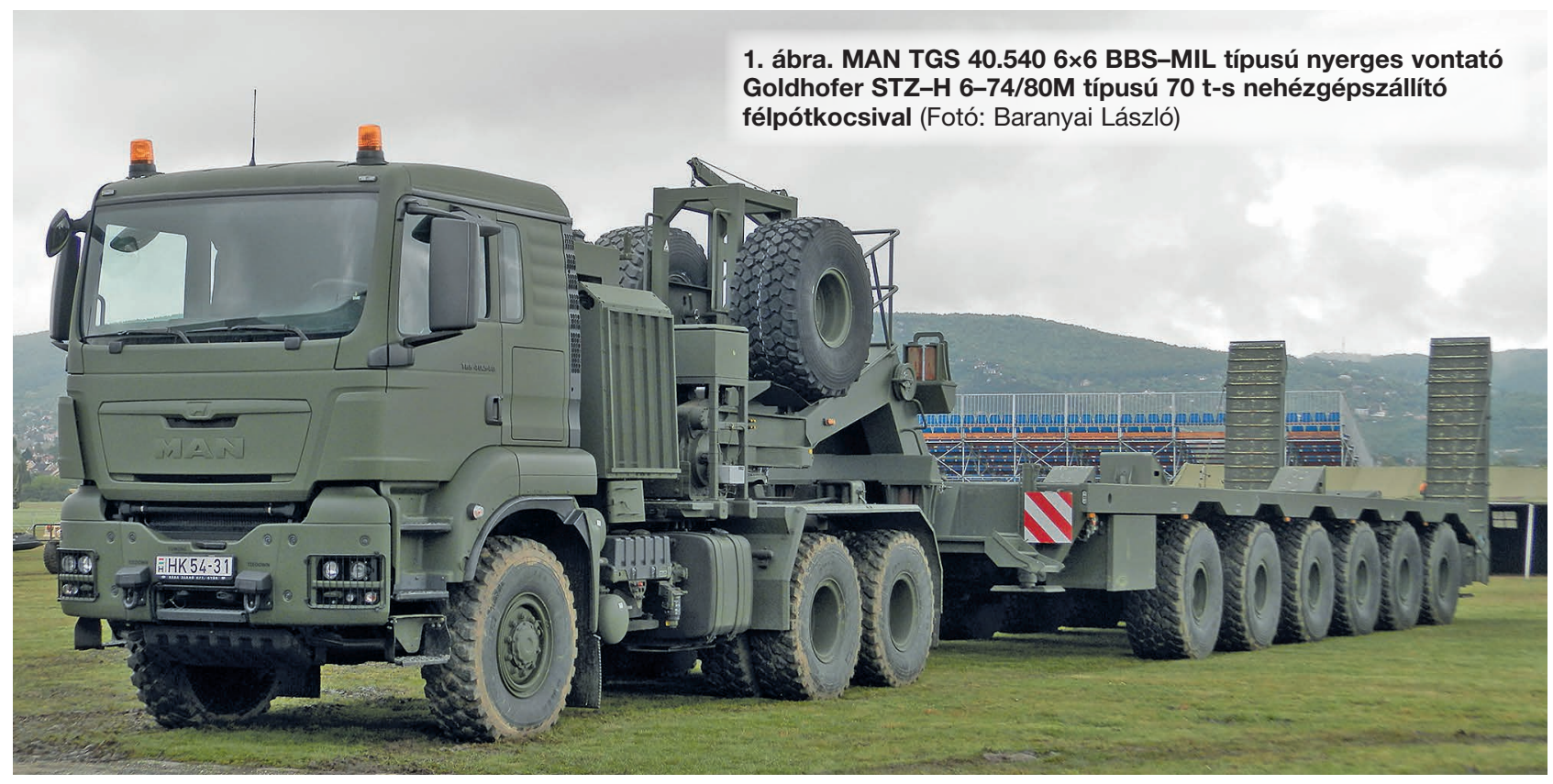

\title{
Farkas Zoltán*
}

\section{Új típusú nehézgépszállító szerelvények}

A Magyar Honvédség (továbbiakban: MH) korszerűsítése, technikai fejlesztése részeként a Zrínyi 2020-2026 honvédelmi és haderőfejlesztési program keretében szükségessé vált egy új típusú, korszerű nehézgépszállítóeszköz beszerzése. A korábban rendszerben tartott nehézgépszállító pótkocsik (traillerek) 40 t terhelhetőségűek voltak, (CSMZAP-5208, T-815 P50N) és a korszerű követelményeket technikai paramétereik miatt nem tudták teljesíteni. Az új szerelvényekkel szemben követelményként szabták meg - és ebben meghatározó szempont volt a Leopard 2 harckocsik közelgő beszerzése - hogy teherbírásuk 70 t legyen. Emellett előírák, hogy az eszköz alkalmas legyen a katonai szervezeteknél jelentkező technikai mentési, katasztrófavédelmi feladatok ellátására, az üzemképes vagy üzemképtelenné vált harcjárművek, műszaki gépek megbízható szállítására közúton és terepen.

A Magyar Honvédség hazai és missziós katonai szervezeteinél, a közúti és terepen történő biztonságos nehéz-

ÖSSZEFOGLALÁS: A Magyar Honvédség a Zrínyi 2020-2026 program keretében korszerü, a NATO-szabványainak megfelelő nehézgép-, illetve harcjármüszállítási feladatok ellátására alkalmas jármüszerelvényeket szerzett be 2017-ben. A MAN TGS $40.5406 \times 6$ BBS-MIL típusú nyerges vontatóból és a Goldhofer STZ-H 6-74/80M típusú 70 t-s nehézgépszállító félpótkocsiból álló járműszerelvény a Leopard 2 harckocsi és a PzH 2000 típusú önjáró löveg biztonságos szállítására is alkalmas.

KULCSSZAVAK: MAN TGS $40.5406 \times 6$ BBS-MIL, Goldhofer STZ-H 6-74/80M, nehézgép- és harcjármüszállitás, Magyar Honvédség, Zrínyi 2020-2026 program gép-szállítás céljára - kipróbálásra - 2 db járműszerelvényt rendelt meg. Mindkét félpótkocsi vontatója a MAN TGS 40.540 6×6 BBS-MIL típusú, háromtengelyes, összkerékhajtású nyerges vontató. A terepen történő mozgáshoz a Goldhofer STZ-H6-74/80M hattengelyes nehézgépszállító nyerges félpótkocsi (1. ábra), a közúti szálításhoz a Goldhofer STZ-H6 (245) M típusú, hattengelyes nehézgépszállító nyerges félpótkocsi (2. ábra) alkalmas. (A nyerges vontató és a terepen történő szállításra alkalmas félpótkocsi együttes tömege $70 \mathrm{t}$, a közúti szállítást biztosító félpótkocsi és a nyerges vontató együttesen 60 t tömegű.) Az STZ-H 6 (245) M típusú („kiskerekes”) nehézgépszállító félpótkocsi részletes ismertetésére jelen cikkben nem térünk ki, alapvető műszaki adatait - a két félpótkocsitípus összehasonlításának bemutatása céljából - az 1. táblázat tartalmazza.

A MAN TGS 40.540 6×6 BBS-MIL típusú nyerges vontató Goldhofer STZ-H 6-74/80M típusú nehézgépszállító

ABSTRACT: In 2017, within the framework of the Zrínyi 2020-2026 program, the Hungarian Defence Forces acquired state-of-the-art vehicle combinations capable of transporting heavy machines and combat vehicles. The combination of a MAN TGS $40.5406 \times 6$ BBS-MIL tractor head and a Goldhofer STZ-H $6-74 / 80 \mathrm{M} 70$ theavy machinery semi-low-loader is also suitable for the safe transport of Leopard 2 tank and PzH 2000 self-propelled howitzer.

KEY WORDS: MAN TGS 40.540 6x6 BBS-MIL, Goldhofer STZ-H 6-74/80M, transportation of heavy machines and combat vehicles, Hungarian Defence Forces, Zrínyi 2020-2026 programme

\footnotetext{
Nyá. mérnök alezredes, a Zrínyi Miklós Akadémia oktatója 1990-1995 között. ORCID: 0000-0002-5680-8872
} 


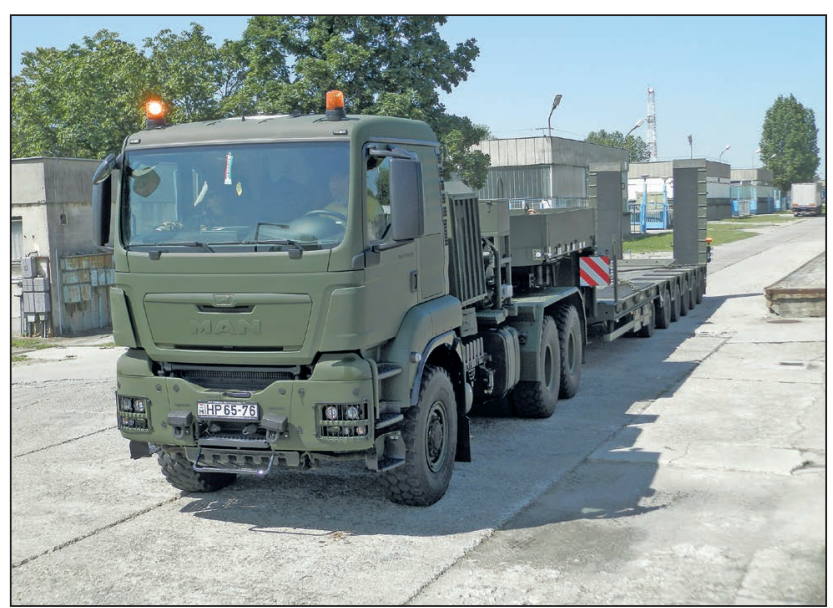

2. ábra. MAN TGS $40.5406 \times 6$ BBS-MIL típusú nyerges vontató Goldhofer STZ-H 6 (245) M típusú nehézgépszállító félpótkocsival (Fotó: Baranyai László)

félpótkocsiból álló járműszerelvény az európai út- és átlagos időjárási viszonyok között $-30{ }^{\circ} \mathrm{C}$-tól $+40{ }^{\circ} \mathrm{C}$-ig üzemeltethető.

Műszakilag és hatóságilag a szerelvény megengedett összes gördülő tömege 120 t, és ezt a tömeget az acélrugók nyomásszenzora határolja le.

\section{A MOTOR ÉS KISZOLGÁLÓ RENDSZEREI}

A kifejezetten nehéz vontatási feladatokra kifejlesztett jármű motorja egy MAN gyártmányú D 2676 LF 08 típusú, EURO 5 emissziójú, SCR (AdBlue) adagolással, négyüte-

3. ábra. A MAN gyártmányú EURO 5/EEV (fokozottan környezetkímélö) motorteljesítmény- és nyomatékgörbéi

\section{D2676 CR (EURO 5/EEV)}

\section{D2676}

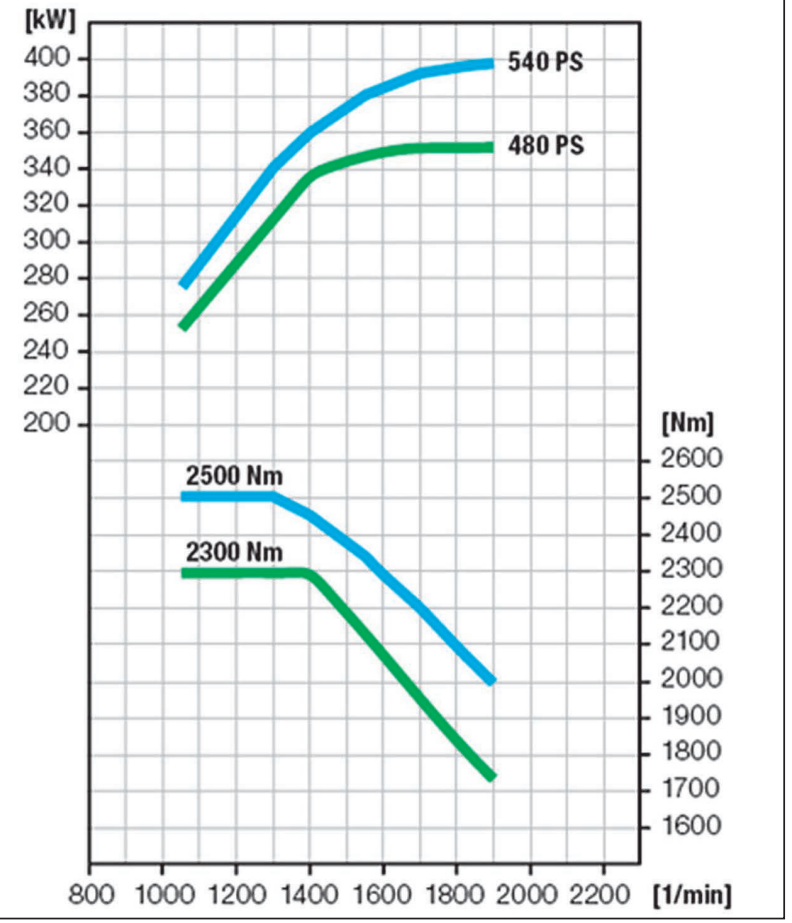

mű, álló, soros, 6 hengeres folyadékhűtéses dízelmotor „common rail” befecskendezési technológiával, turbófeltöltéssel és töltőlevegő visszahütéssel. Teljesítménye 397 kW (540 LE) 1900 1/min fordulatszámnál. Az optimális felépítésű motor kiváló tömeg-teljesítmény arány mutatókkal rendelkezik, alacsony fordulatszámon is nagy nyomatékot ad le (lásd: 3. ábra) és a tüzelőanyag-fogyasztása is alacsony. A jármű fajlagos teljesítménye 120 t összgördülő tömegnél 3,31 kW/t.

A teljes terheléssel történő folyamatos üzemeltetést a megnövelt teljesítményű hűtő- és fékrendszer garantálja.

$A$ jármű EDC elektronikus motorvezérlési elektronikával rendelkezik, amelynek egyik funkciója a rögzíthető fordulatszám-beállítás. A motor emissziós határértékeinek betartását az On Board diagnosztika (OBD 2) felügyeli, oly módon ellenőrizve, hogy nyomatékkorlátozás nem jön létre. Az indítás megkönnyítésére lángindító berendezéssel látták el. Ez a berendezés 20-30 sec előizzítás után, a motor indítása közben tüzelőanyagot juttat be a szívócsőbe, amely meggyulladva felmelegíti a beszívott levegőt. A hidegindítást $-30^{\circ} \mathrm{C}$-ig biztosítja.

A hưtést termosztát szabályozású kényszercirkulációs, túlnyomásos folyadékhütéses rendszer biztosítja. A ventilátort viszkó csatlakozóval szerelték fel. Amikor a tengelykapcsoló eléri az előre meghatározott hőmérsékletet, akkor bekapcsolja a ventilátort. A hütőrendszer szükség esetén - a kezelési utasításnak megfelelően - vízzel is feltölthető, amelyet a „szükségállapot” megszűnése után fagyálló hűtőfolyadékra kell cserélni. A hűtőradiátor kőfelverődés elleni védelmét rácsszerkezet biztosítja. $A$ gyártó a hűtőrendszert $-37^{\circ} \mathrm{C}$-os fagyálló hűtőfolyadékkal látta el.

$A$ járművet a nehéz vontatási feladatok érdekében megnövelt teljesítményű, a fülke mögé szerelt kiegészítő hűtőradiátorokkal (hűtőlevegő, hűtőfolyadék, olaj) látták el, amelyeket hidrosztatikus hajtású ventilátor hűt. A megnövelt hütőkapacitás $+35^{\circ} \mathrm{C}$ hőmérséklet feletti üzemelést is lehetővé tesz.

A járműszerelvény nagy össztömegnél vagy szélsőséges környezeti hőmérséklet feletti üzemeltetésnél a motorelektronika a teljesítményt max. 25\%-kal csökkenti. Ez azt eredményezi, hogy lehetővé teszi a $+50{ }^{\circ} \mathrm{C}$ környezeti hőmérsékleten való megbízható üzemelést is.

A jármű álló helyzetében a motorteljesítmény 25\%-kal csökkenthető a beépített mellékhajtásokon keresztül. Alapjáratközeli tartós üzem ugyan megengedett, de ekkor számolni kell azzal, hogy a mellékhajtás és a meghajtott berendezés teljesítmény- és nyomatékigénye függvényében, a motor élettartama csökkenhet.

4. ábra. A nagyméretű hútőradiátor és a TGS Sepson csörlő bal oldali, leeresztett csörlökötéllel

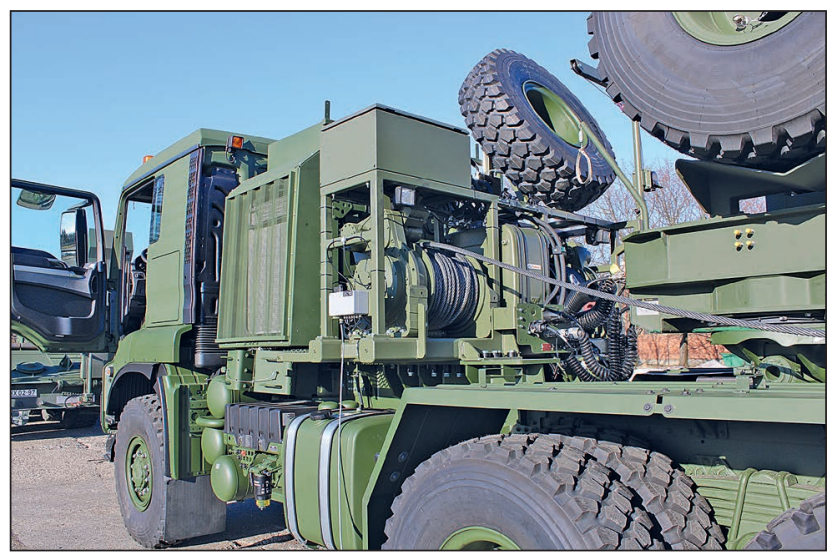




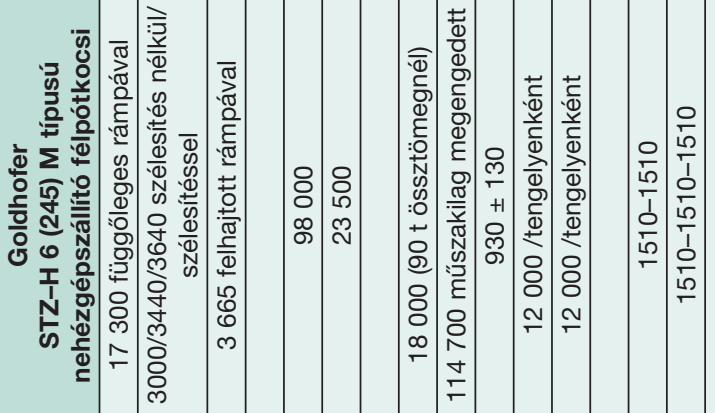

㠃

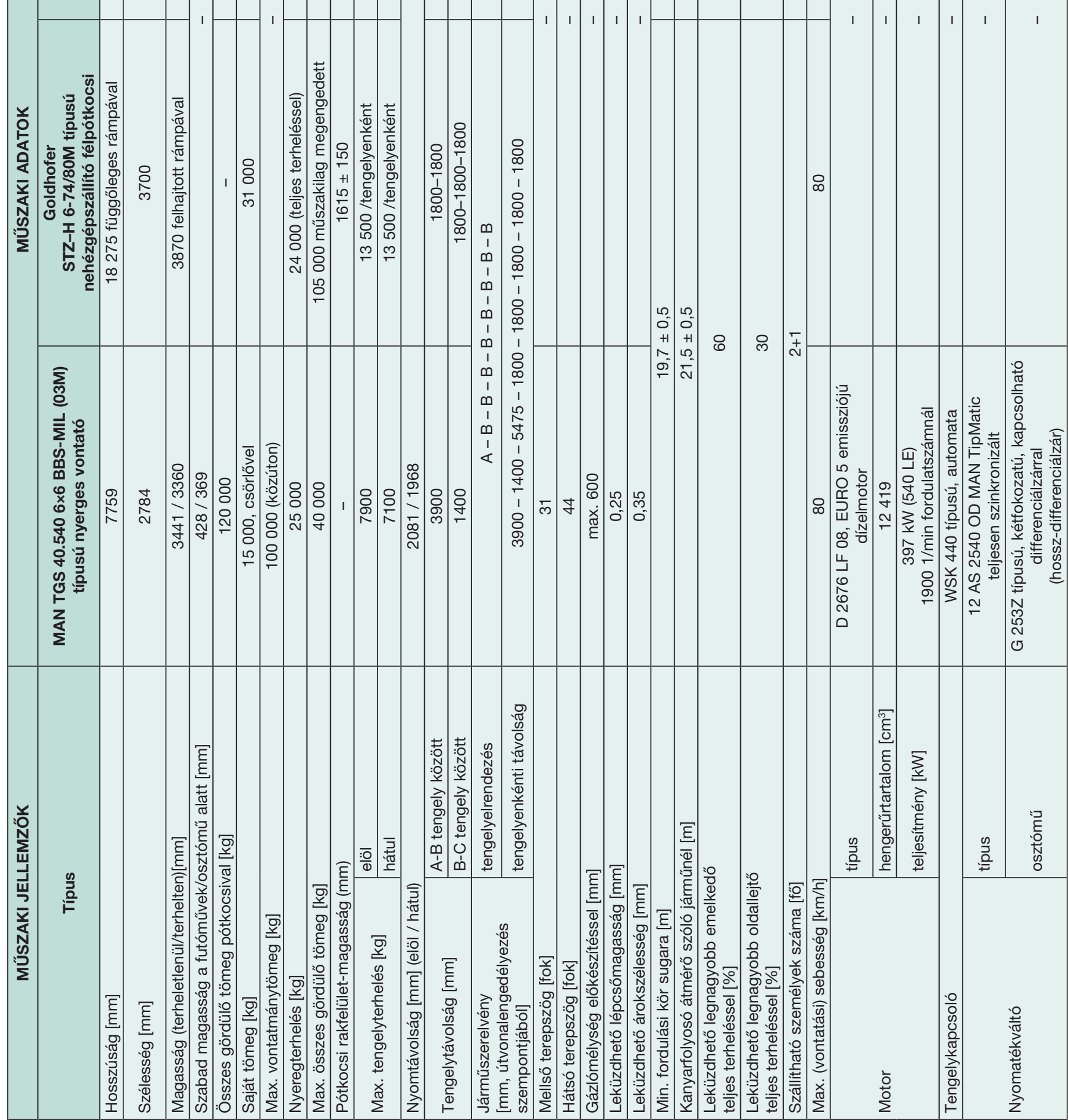




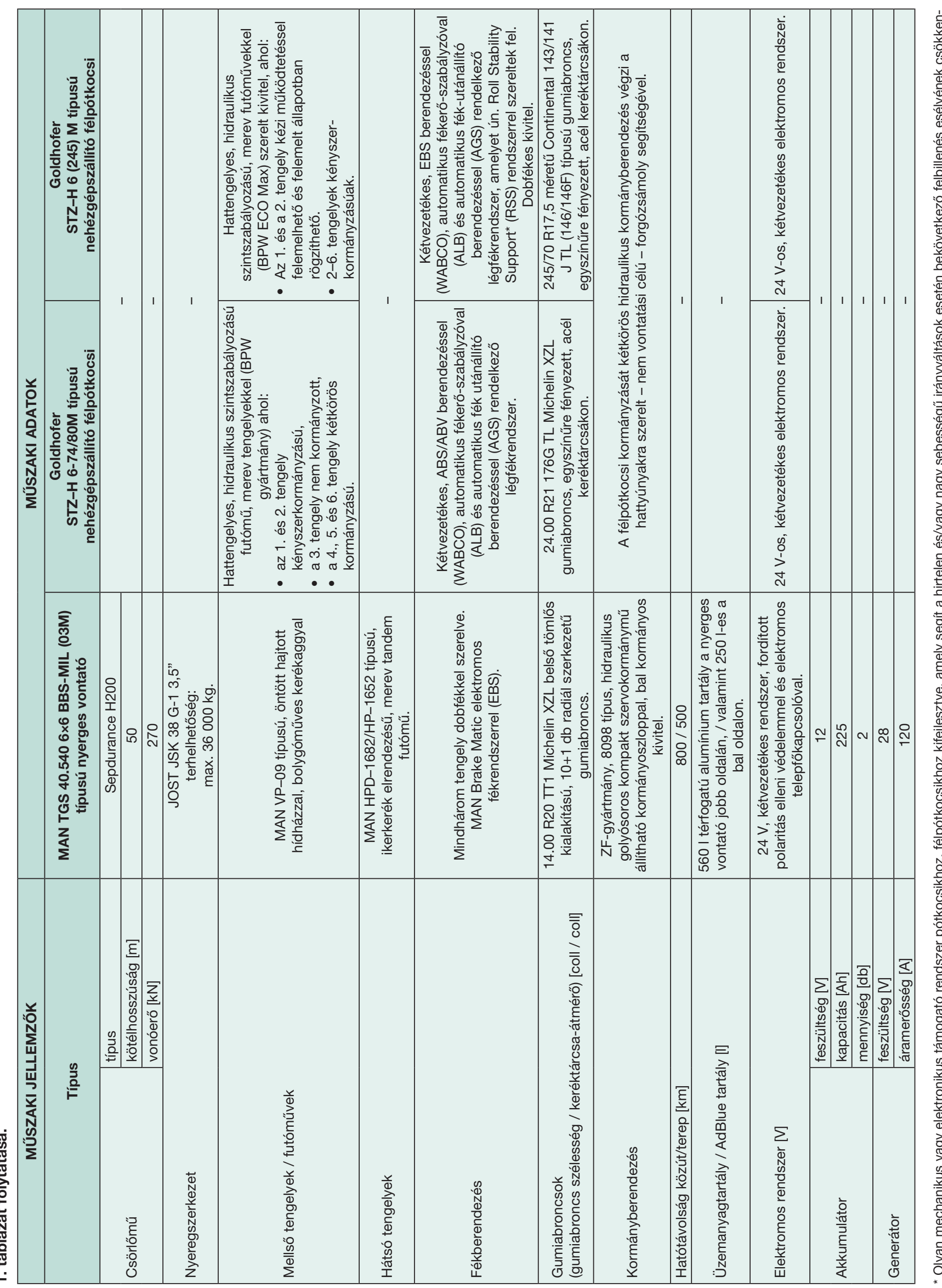

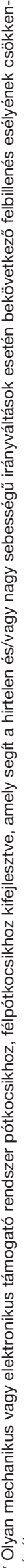


Növelt hatású kipufogófékkel rendelkezik, amelynek teljesítménye 2400 1/min. fordulatszámnál 285 kW. Hatásossága a motor fordulatszámától függ és a kipufogócsőben elhelyezett fojtószelep 30\%-kal növeli a kipufogófék teljesítményét. A kipufogócsöveket a vezetőfülke mögött vezetik ki; a távozó kipufogógázok katalizátoron keresztül jutnak a szabadba. Az On Board fedélzeti diagnosztika felügyeli a motor emissziós határértékeinek betartását. $A z$ EURO 5 koncepció megvalósítása magában foglalja a magas égési csúcshőmérsékletet, az alacsony tüzelőanyag-fogyasztást, az alacsony részecske-kibocsátást. A magas $\mathrm{NO}_{\mathrm{x}}$ kibocsátást az Adblue adagolással működő SCR (selective catalyte reduction) katalizátor csökkenti a határértékek alá. Az Adblue szintetikus karbamid vizes oldata a kipufogógázok utókezeléséhez, redukálószerként kerül alkalmazásra. $\mathrm{A} \mathrm{NO}$ nitrogén-oxidokat környezetbarát anyagokká (nitrogén és vízgőz) alakítja át.

A motor levegőellátó rendszere előszűrővel felszerelt, papírbetétes levegőszűrős konstrukció, amely a nehéz terepen történő igénybevételhez készült, automatikus, ciklon rendszerű leválasztó funkcióval és elektronikus eltömődéskijelzővel alakították ki. A levegőszűrőt a vezetőfülke alatt az alvázon helyezték el.

A normál üzemeltetést az F-54 és az F-65 téliesített katonai üzemanyagok biztosítják. Az F-34 üzemanyaggal történő üzemeltetés megengedett, ebben az esetben azonban teljesítménycsökkenéssel, romló emissziós értékekkel és a befecskendező rendszer élettartamának csökkenésével kell számolni. A kenőképesség és a cetánszám javítására általában az S1750 NATO-kódú adalékot kell bekeverni. $2000 \mathrm{~m}$ tengerszint feletti magasságon történő üzemeltetésnél $\mathrm{kb}$. 10\% teljesítménycsökkenés várható. $A z$ üzemanyag-táprendszert Separ típusú víztelenítő és füthető üzemanyag-durvaszűrővel látták el.

A vontató és a félpótkocsi féklevegővel való ellátását egy kéthengeres, $720 \mathrm{~cm}^{3}$-es légkompresszor biztosítja.

\section{A HAJTÁSLÁNC}

A WSK 440 típusú automata tengelykapcsoló száraz, kerámia tengelykapcsoló, amelyet összeépítettek a ZF gyártmányú 12 AS 2540 OD MAN TipMatic típusú, teljesen szinkronizált sebességváltóval, és ezeket a hajtásláncelemeket a ZF gyártmányú retarderrel, valamint a hőcserélővel az alumínium házban helyezték el. A tengelykapcsoló túlterhelésre megcsúszó kivitelben készült, tengelykapcsoló pedál nincs.

\section{5. ábra. Az egybeépített hidrodinamikus tengelykapcsoló és} a sebességváltó

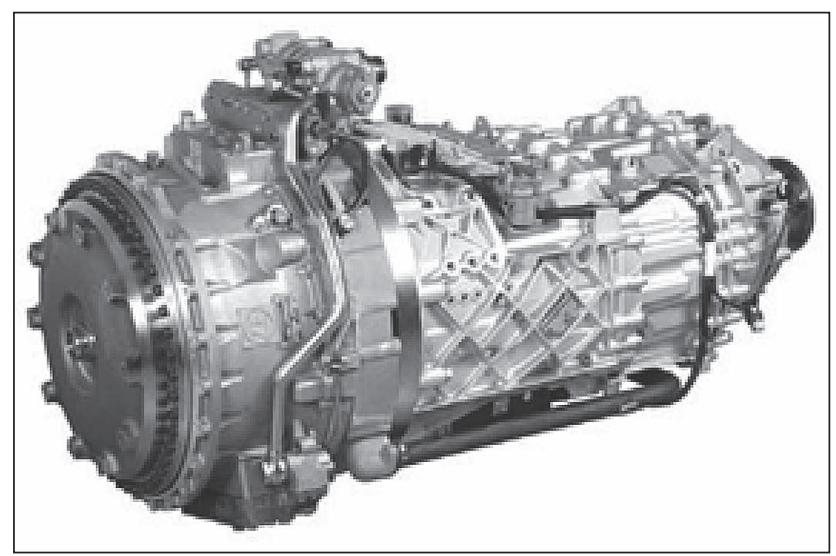

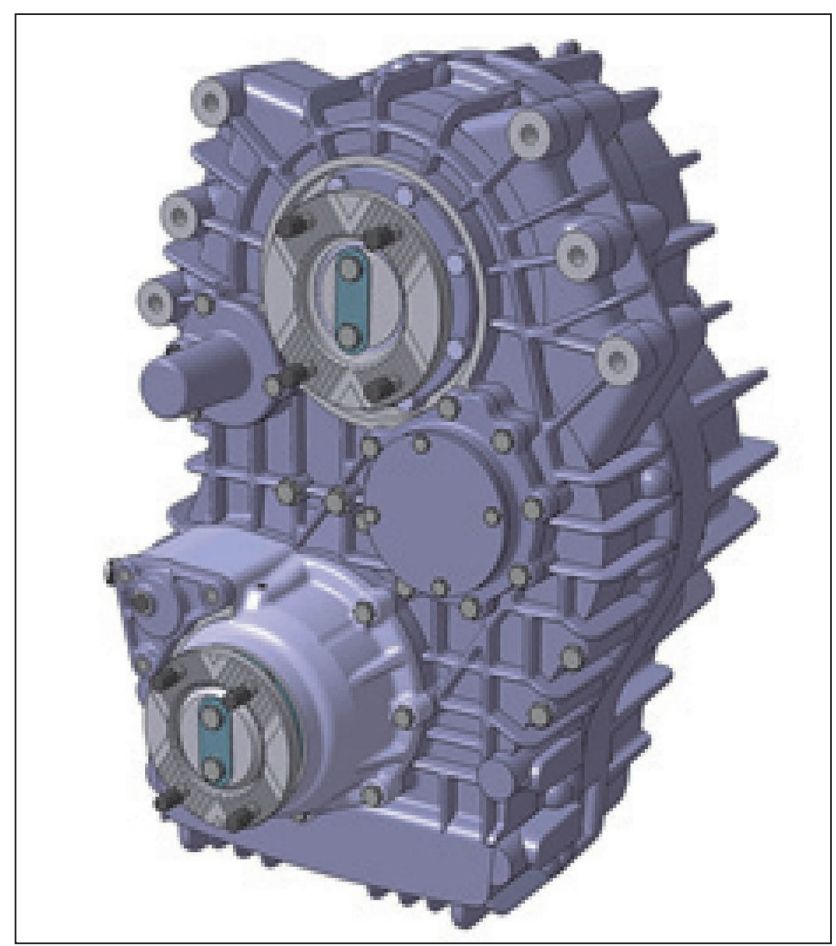

6. ábra. A robosztus felépítésű $\mathrm{G} 253 Z$ típusú osztómű

A fokozatok alapvetően elektro-pneumatikus úton kapcsolódnak, az elektronikus rendszer önállóan választja meg a legmegfelelőbb sebességfokozatot, de különleges esetekben az automatika kiiktatásával is működtethető a sebességváltó. A sebességváltó 12 előre és 2 hátrameneti fokozattal rendelkezik. Az áttételi fokozatok 12,29 és 0,78 értékek közöttiek. A maximális sebességet a sebességkorlátozó (tempomat funkció) $89+1 \mathrm{~km} / \mathrm{h}$-ra szabályozza. A jármű vontatása csak előkészítéssel lehetséges.

Az osztómű biztosítja az üres, az országúti és a terepfokozatok kapcsolását.

A MAN gyártmányú G $253 Z$ típusú kétfokozatú osztómü differenciálzárral (hosszdifferenciálzár) kapcsolható, ahol a maximális bemenő nyomaték $25 \mathrm{kNm}$. A jármű hajtásképlete: $6 \times 6$. A mellső futómű hajtása kapcsolható. Az osztómű külön olajhűtővel rendelkezik.

$$
\begin{array}{lll}
\text { Áttételek: } & \text { - országúti fokozat: } & 1: 0,981 \text {; } \\
& \text { - terepfokozat: } & 1: 1,582 .
\end{array}
$$

A terepfokozat-országúti fokozat csak álló helyzetben kapcsolható.

A különböző üzemmódok kapcsolását az összkerékhajtás-kapcsoló végzi. (7. ábra).

A helyzet: terep áttétel

B helyzet: üres

C helyzet: országúti (közúti) áttétel

Színjelzések: - szürke szín: nem kapcsolt,

- zöld szín: bekapcsolt,

- piros szín: bekapcsolt és zárt helyzet.

A futómű mindhárom hajtott tengelye robosztus felépítésű, bolygóműves hajtással, dobfékkel és laprugós rugózással rendelkezik. Álló helyben a megbízható rögzítést a mindhárom tengelyre ható rögzítőfék biztosítja. A Knorrrendszerü, kétvezetékes üzemi légfék vezérlése elektronikusan történik. Elöl kétvezetékes, passzív fékező vezetékcsatlakozót építettek ki. A fékrendszer offroad ABS, valamint az emelkedőn történő indulást elősegítő (easy start) rendszerrel üzemel. A fékrendszer automata terhelésfüggő fékerő szabályozású. 


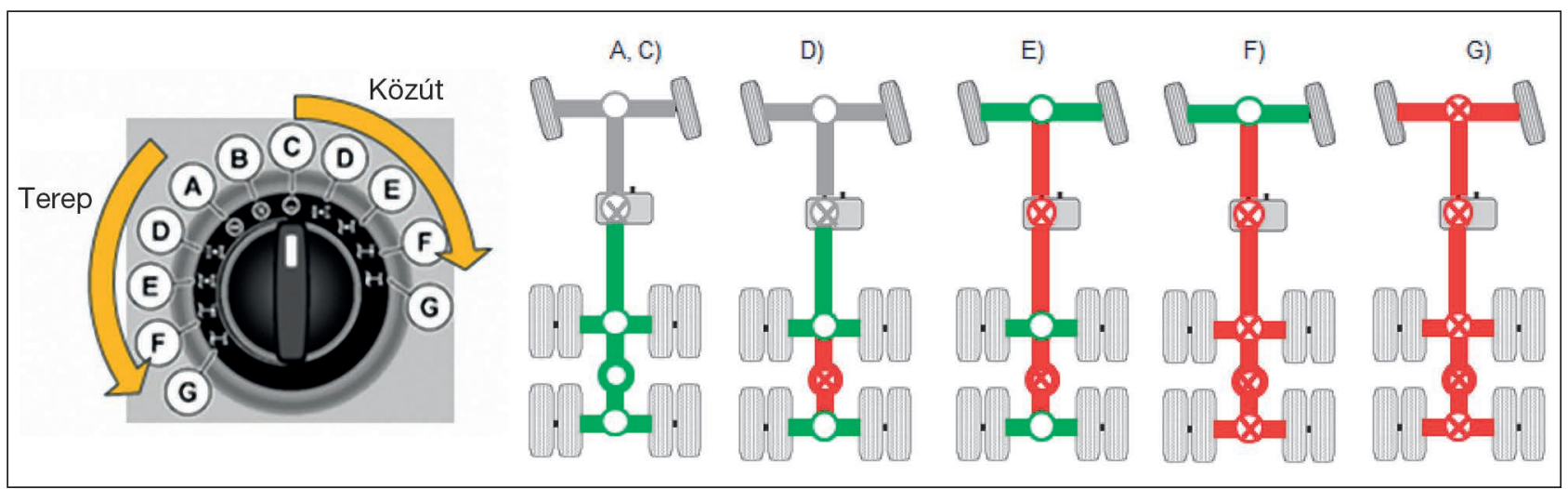

7. ábra. Az összkerékhajtás kapcsolási vázlata

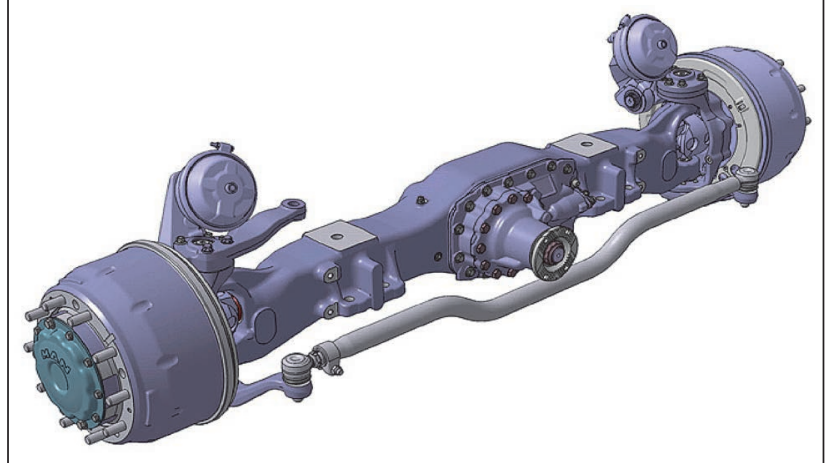

8. ábra. Külsőbolygómúves, dobfékes, kormányzott merev első híd

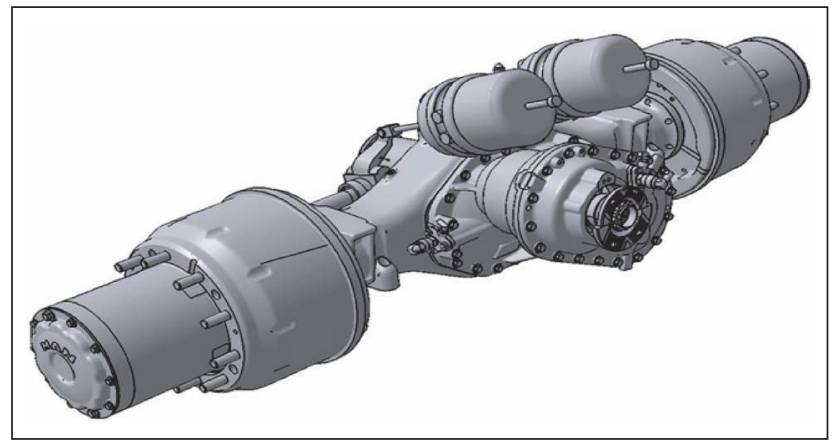

9. ábra. Külső bolygómúves merev hátsó tengely (második tengely)

A vezetőfülke MAN L típusú, balkormányos, 2+1 fő szállítására alkalmas kivitelü, négy ponton spirálrugókkal az alvázon rögzítve. (Rugóút +/- $45 \mathrm{~mm}$.) A fülke billenthetö, a csapágyazásánál speciális elemek lehetővé teszik a hosszirányú elmozdulást, ezzel ütközés esetén a jobb energiaelnyelést. A fülke billentése kézi működtetésű hidraulikus rendszerrel történik. A felbillentett fülke mechanikusan kitámasztható.

A szélvédő sík, ragasztott biztonsági színezett üveg, mechanikus sötétítővel ellátva. Az ajtók ablakai, és a hátsó oldalablakok is színezettek. Függöny körben felszerelve. Az ajtók ablakait elektromos ablakemelővel szerelték fel. $A z$ ajtók központi zárral zárhatók. A jobb és bal oldali ülések légrugósak, a középső ülés felhajtható kivitelű. A kísérőülés melletti ajtó a műszerfalról zárható. Motor-hűtőfolyadékkal működő fülkefütés többfokozatú ventilátorral, ugyanez a berendezés párátlanítja a szélvédőt és az oldalsó ablakokat is.
Az Ebersprächer AIRTRONIC D2 (max. 2,2 kW) állóhelyi fütés, a széria fülkefütéssel együtt biztosítja, hogy $-30^{\circ} \mathrm{C}$ külső hőmérséklet esetén a vezetőfülke padlója felett 300 $\mathrm{mm}$-rel legalább $+5{ }^{\circ} \mathrm{C}$ hőmérséklet legyen. Diagnosztizálható a MAN Cats rendszerrel.

A járművet finom- és pollenszűrővel szerelték fel, a vezetőfülkét klíma-berendezéssel látták el.

A kabin hátsó fala ablak nélküli.

A szélvédőn többfokozatú és szakaszos működtetésű ablaktörlőket helyeztek el. A jármű a katonai előírásoknak megfelelően rejtett fényű világítással, és elektromosan működtethető fényszóró-magasságállítási lehetőséggel rendelkezik.

A vontató meghibásodása, esetleges elakadása esetén elöl, a vontató hossztartóihoz erősített kengyelekhez rögzíthető a vontatószerkezet. Egy kengyelhez történő és a hossztengellyel párhuzamos vontatás esetén a megengedett maximális terhelés 20 t. Ferde vontatás esetén a maximális terhelés csak $10 \mathrm{t}$.

A multifunkcionális kormánykerék magassága a középhelyzethez képest $\pm 40 \mathrm{~mm}$-rel, dőlésszöge a $60^{\circ}$-os beépítési középhelyzethez képest $+10 /-11^{\circ}-$ kal állítható. A vezető centrális látóterében elhelyezett „High-Line” műszerfal tartalmazza az összes mérőműszert, jelző és működtető szerelvényt, amely a jármű működtetéséhez és felügyeletéhez szükséges. A járműelektronika összehangolt működéséről a MAN Tronic típusú fedélzeti számítógép gondoskodik, amely rendelkezik digitális kijelzővel, és - az $\mathrm{MH}$ által beszerzett változatokban - a kezelővel magyar nyelvű információkat közöl.

Az erőátviteli szervek véletlenszerű kapcsolás elleni védelemmel rendelkeznek. A műszerfal fényereje változtatható, a funkciókapcsolók kapcsolási állapotát és az üzemeltetés szempontjából fontos információkat műszer, illetve jelzőfény mutatja. A kezelőszervek elhelyezése és kialakítása lehetővé teszi a katonai gyakorló öltözet téli változatában, illetve vegyivédelmi védőruhában is a jármű biztonságos kezelését.

Fontosabb müszerek: sebességmérő, km-számláló, digitális tachográf, fordulatszámmérő, fékkörök nyomásmérői, olajnyomásmérő, hűtővíz-hőfokmérő, üzemanyagszintmérő, óra, üzemóraszámláló.

Fontosabb kapcsolók: világításkapcsoló, műszerfalvilágítás-szabályzó, elakadásjelző, ködzárófény, mellső futómű differenciálzár, hátsó futómű differenciálzár, osztómű országúti-terepfokozat, osztómú differenciálzár, mellékhajtómű kapcsolója. (Be- és kikapcsolásuk a gyártó előírásai szerint.)

Fontosabb jelzőfények: fülkerögzítés, motorindíthatóság (több ellenőrzőlámpa kombinációja), központi hibajelző, fékkör I-II. nyomásjelzés, kézifék, EBS, hűtővíz-hőfok, mo- 
torolaj-nívó, olajnyomás, lángindító, irányjelző, távfény, differenciálzárak, osztómű és mellékhajtómű visszajelző fényei.

A vezetőfülke belső tere lehetővé teszi a személyzet egyéni felszerelésének, a fülkében elhelyezendő kiegészítő felszerelések és berendezések biztonságos elhelyezését és rögzítését. A vezetőfülke alsó és felső hálóhellyel is rendelkezik. A vezetőfülke külső részén zárható málhatereket alakítottak ki.

A vezetőfülkébe történő biztonságos fel- és leszálláshoz fellépők, továbbá a bent ülők menet közbeni biztonságához célszerüen elhelyezett kapaszkodók állnak rendelkezésre, valamint ajtónyitáskor bekapcsolódó belső világítás biztosított mindkét oldalon.

A vezetőfülke konstrukciós kialakítása, tömítettsége alkalmas túlnyomásos tér létrehozására. Ehhez megfelelő további intézkedésekre és berendezésekre van szükség.

A belső berendezés és a bevonatok anyaga önkioltó, a szennyező anyagoknak (víz, üzem- és kenőanyagok) ellenáll. A fülke padlója műanyag burkolatú. A belső tér korlátozottan vegyimentesíthető. MAN Basic Line rádió CD-lejátszóval és biztonsági funkciókkal beépítve. A tetőablak kézi működtetésű, két beállítási lehetőséggel, a tető síkjába integrálva.

\section{AZ ALVÁZ}

Nagy szilárdságú, U profilú hossztartók, kereszttartókkal összekötve, létraváz kialakításban. Az alváz elöl szabványos vonócsappal és $2 \mathrm{db}$ vonószemmel ellátott kereszttartóval és megerősített 3 részes acél lökhárítóval, hátul vonókészülék fogadására alkalmas záró kereszttartóval záródik. A jármű mellső részét és a motortér alját háromrészes mellső lökhárító védi a mechanikai sérülésektől.

A létravázra, félpótkocsi vontatáshoz, illetve a nyeregszerkezet fogadásához segédalvázat szereltek fel.

Az alvázon, a fülke mögött munkafelületet alakítottak ki lépcsőkkel és kapaszkodókkal, feljárás a menetirány szerinti bal oldalon. Az első lépcsőfok a vezetőfülkénél eltávolítható. Az első sárvédőket felfröccsenésgátlóval szerelték fel, míg a hátsó tengelycsoportot háromrészes acél sárvédők védik.

\section{A SEPDURANCE H200 TÍPUSÚ CSÖRLÖMÜ}

A sérült, üzemképtelen eszközök szállítótérre történő felvontatását a vontató járművön elhelyezett csörlők teszik lehetővé. A csörlőket a hütőkeret mögött, a jármű jobb és bal oldalán, a működtető hidraulika rendszerrel együtt helyezték el.

A csörlő a nagy igénybevétel miatt gömbgrafitos öntöttvas dobbal és házzal, rugóerő-tárolós, nyomáscsökkentő szeleppel, valamint többtárcsás fékkel készült. A 25 t vonóerővel rendelkező hidraulikus hajtású csörlő 160-250 bar nyomástartományban üzemel. A csörlő kétsebességű, amely a csévélést nagy, illetve kis sebességgel végzi. A felés lecsévélési sebességek ettől függően az alsó, illetve felső kötél ágon az $5 \mathrm{~m} / \mathrm{sec}$-tól a $21 \mathrm{~m} / \mathrm{sec}$ sebességet teszik lehetővé. A $26 \mathrm{~mm}$ átmérőjű csörlőkötél a dobon négy rétegben helyezkedik el, de a rétegek számától függetlenül állandó vonóerőt biztosít. A kötélvezető rendszer beállításához a csörlődob és a vezető szerkezet kézi forgatással működtethető. A kötél szabadonfutását biztosító tengelykapcsoló pneumatikus működtetésű. Kis sebességű üzemmódban a kötél húzóereje alsó soron 250 kN, ahol a maximális vonóerő $270 \mathrm{kN}$.

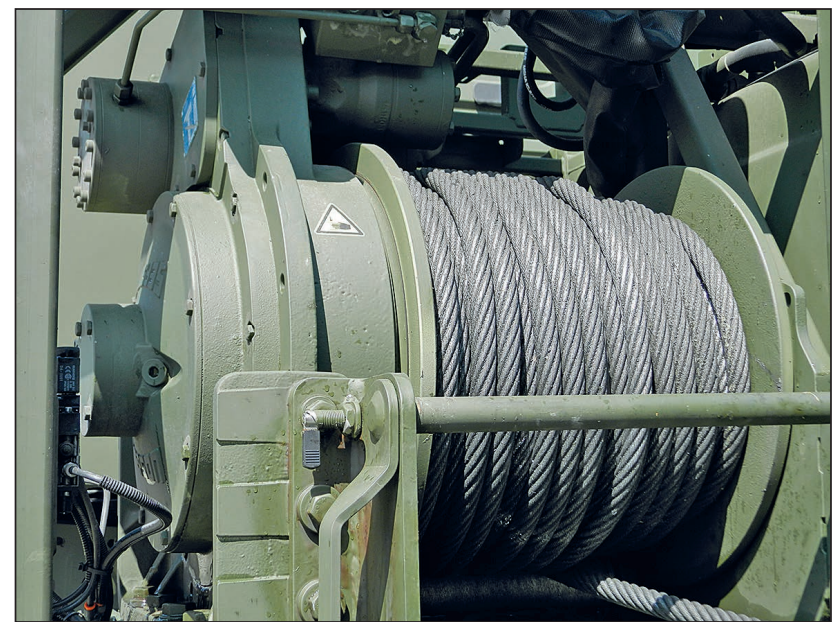

10. ábra. A csörlő és a csörlődob a vontatón (Fotó: Baranyai László)

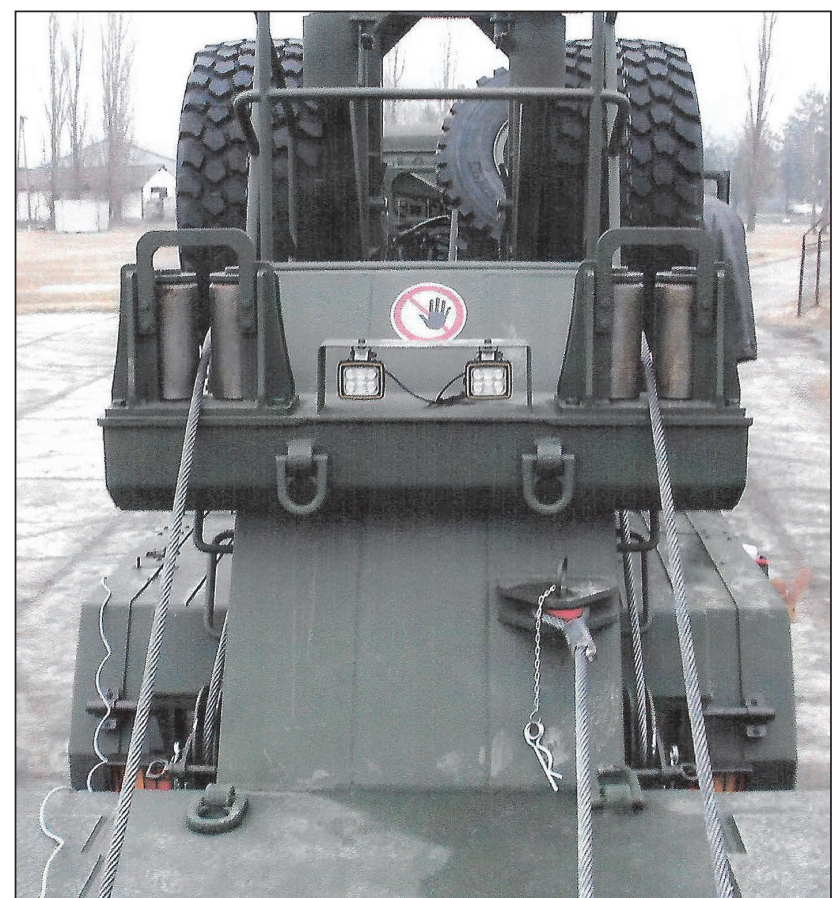

11. ábra. A csörlőkötelek vezetőgörgői és kötélvég rögzítése a hattyúnyakon

A járműszerelvényen alkalmazott festékbevonatok, szerkezeti anyagok, a tömítő és burkoló anyagok ellenállnak az ultraibolya sugárzás, az ABV szennyező anyagok és a mentesítő anyagok hatásainak.

Az MAN TGS 40.540 6×6 BBS-MIL típusú terepjáró nyerges vontató vasúti szállítása $800 \mathrm{~mm}$ magasságú vasúti kocsin - minimális előkészítéssel - lehetséges. A vontatott félpótkocsi vasúti szállítása a vontatótól lekapcsolva külön történik.

\section{A FÉLPÓTKOCS}

Hegesztett acélkonstrukció kiemelt hattyúnyakkal és hátul járható srégeléssel. Az alváz csavarásnak ellenálló, a jármű a közepén végigfutó négyszög keresztmetszetű hossztartóra (gerinc) épül, amelyhez kereszttartók kapcsolódnak 


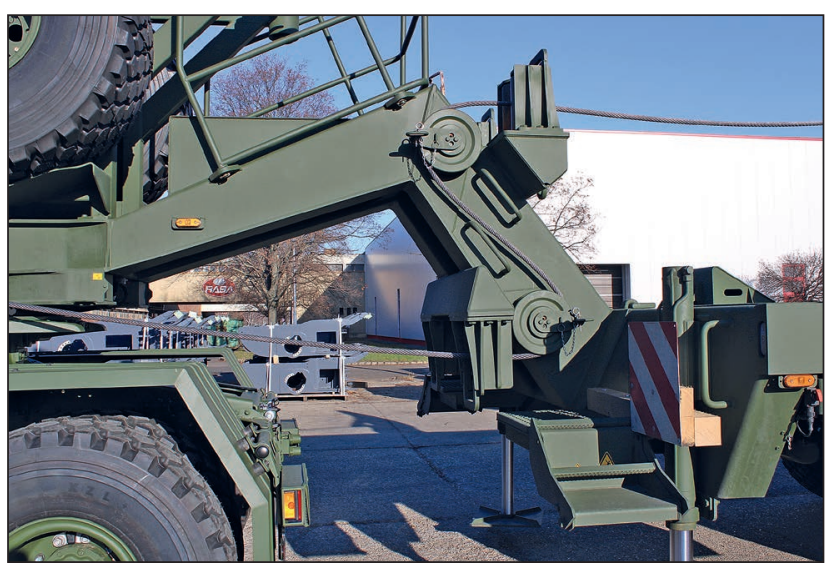

12. ábra. A félpótkocsi hattyúnyaka a letalpalt félpótkocsival

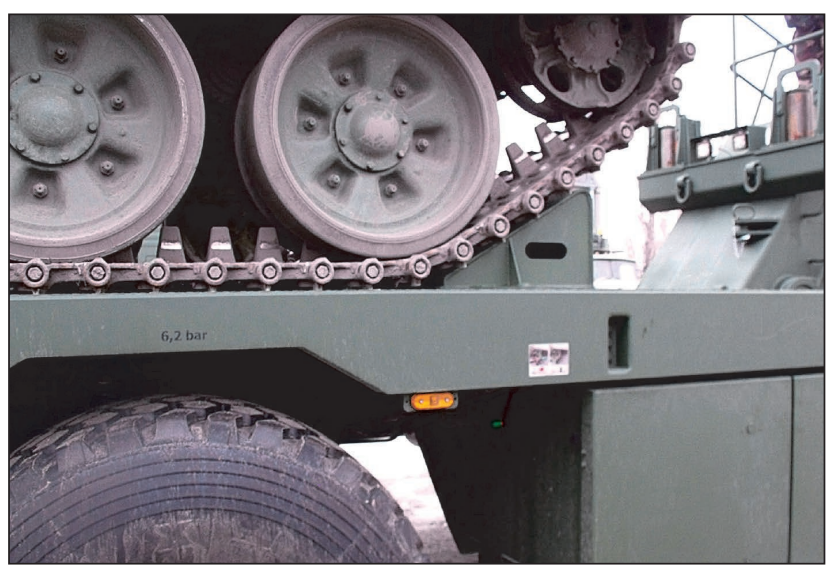

13. ábra. Rögzítőék elhelyezése a lánctalp előtt

jobb és bal oldalon. Ezek a félpótkocsi szélén vannak öszszekötve, így az alváz zárt keretet alkot. Az alváz oldalán - a 4. és 5. tengelynél - mindkét oldalon fellépő létra van.

A félpótkocsi padlófelülete a futómúvek felett is teljesen sík, acélkonstrukció. Hosszúsága 14000 mm, szélessége $3700 \mathrm{~mm}$, hátul a felhajtó srégelés vetületi hossza $1300 \mathrm{~mm}$. Ahol a lánctalpas eszköz elhelyezkedik, ott az acélrakfelület bordázott. A rakfelület magassága - a légrugós felfüggesztés miatt - állítható a vontató jármű segítségével. (1615 $\pm 150 \mathrm{~mm})$. A padlón 4 pár állítható lánctalpvezető, valamint 2 pár lánctalpkitámasztó ék található, 2 különböző lánctalpszélességhez.

\section{4. ábra. Elektromos és hidraulika rendszer csatlakozói}

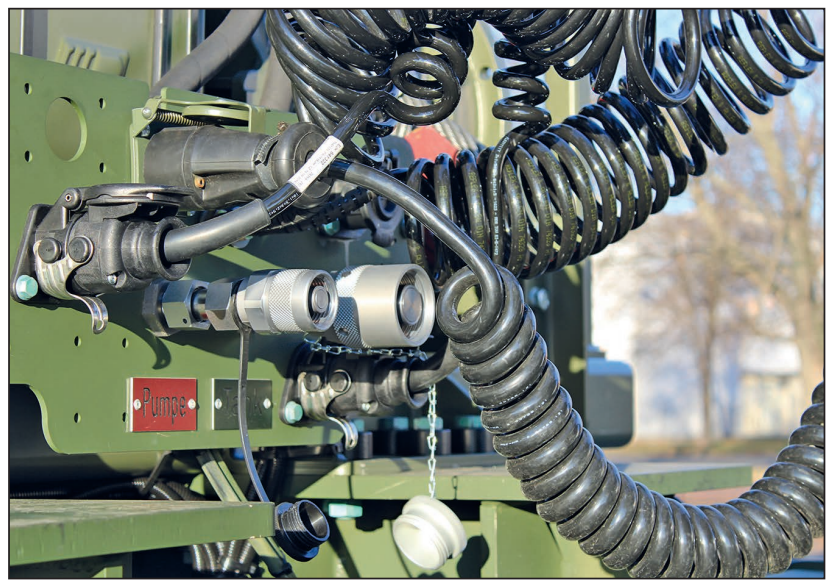

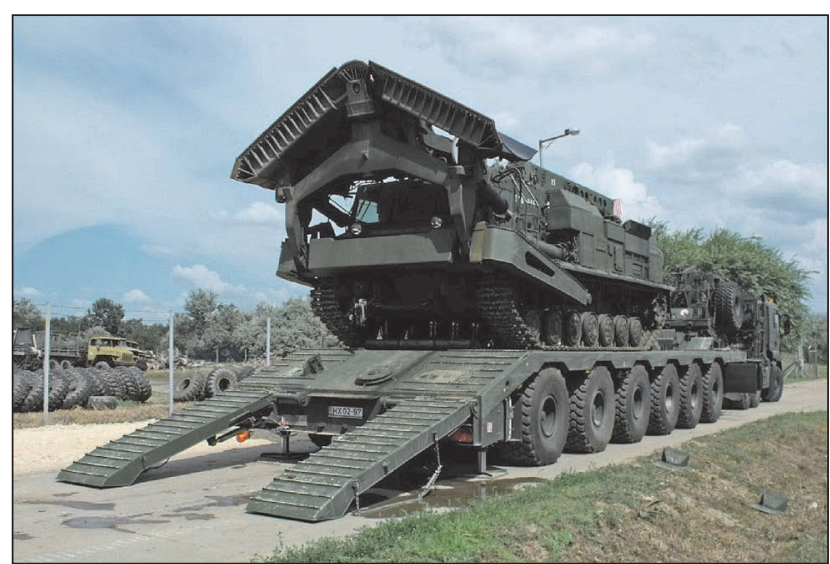

15. ábra. A BAT 2 típusú müszaki gép lerakodás előtt

A félpótkocsi rakodófelületét, a srégelést, a rámpák és a hattyúnyak járófelületeit csúszásmentes bevonattal látták el. A bordázott felületű acélsrégelés alatt egy pár kitámasztó lábat szereltek fel, amely segíti a biztonságos fel- és lerakodást. Az itt elhelyezett kitámasztó lábak hidraulikus működtetése a félpótkocsi bal oldaláról történik. Ugyanebből a hidraulikus vezérlőegység dobozból vezérelhető a rámpamozgatás is.

A félpótkocsi hátsó részére 1 pár hidraulikusan mozgatható, $2850 \mathrm{~mm}$ hosszú, $800 \mathrm{~mm}$ széles, egyrészes felhajtórámpát szereltek fel, acélpadlós borítással. Leeresztve $20^{\circ}$-os a lejtése.

A hidraulikus rámpa energiatáplálása a vontató gépjárművön meglevő 2 csöves hidraulikarendszerről történik, a hattyúnyakon elhelyezett gyorscsatlakozókkal. Vészmüködtetés kézi szivattyúval is lehetséges.

A rakfelületen lekötöző/emelő pontokat alakítottak ki:

- 1 pár lekötöző gyűrű a hattyúnyakra felszerelve,

- 7 pár lekötöző gyűrű a padlón és a srégelésen,

- 2 pár 10 t-s emelőfül, daruval történő mozgatáshoz.

A félpótkocsi rendelkezik egy készlet kötélvezető mechanizmussal, amely a vontató jármű kétcsörlős rendszeréhez illeszkedik annak érdekében, hogy az üzemképtelen lánctalpas eszközöket a félpótkocsira fel és le lehessen rakodni. A rendszer elemei:

- $4 \mathrm{db}$ függőleges irányba terelő kötélgörgő a hattyúnyakon,

- 1 db vízszintes irányba terelő osztott görgő a félpótkocsi végén,

- 1 db függőleges irányba terelő görgő a srégelésnél,

- 4-szárú lánc, $\Omega$-kengyelek.

A hattyúnyakat 3 tengelyes $(6 \times 6)$ és 3900 mm tengelytávú vontató járművel történő vontatáshoz alakították ki. A hatytyúnyakon helyeztek el $2 \mathrm{db}$ hidraulikus kormánygépet, amely a félpótkocsi kétkörös kormányzási rendszerének része. A félpótkocsi 4.; 5. és 6. tengelyei a fenti módon kormányozhatók. $A z 1$. és 2 . futómü - a pótkocsi ideális fordulókörére illeszkedő - inverz kormányzási szöget, egy speciális karos mechanizmuson keresztül a 4. tengelyről kapja.

\section{FELHASZNÁLT IRODALOM}

TGS 40.540 6×6 BBS-MIL (03M) típusú háromtengelyes

összkerékhajtású nyergesvontató műszaki specifikáció; Goldhofer 70 tonnás trailer kezelési utasítás;

TGS Sepson 25 tonnás csörlő kezelési utasítás;

MAN TGS 40.540 6x6 BBS 186100-m01 műszaki specifikáció. 